\title{
THE DIFFERENT RECOGNITION MECHANISM OF CARBAZOLE DERIVATIVES FOR BIOLOGICAL IMPORTANT ANION: THEORY AND EXPERIMENT
}

\author{
XUEFANG SHANG ${ }^{a *}$, HONGWEI WU ${ }^{a}$, SHENYU JIA ${ }^{b}$, JIE HAN ${ }^{b}$, YUN LIU ${ }^{b}$, ZHENYA YIN $^{b}$, XIAOJIAO QIN , \\ JINLIAN ZHANG ${ }^{b}$, XIUFANG XU
}

\author{
${ }^{a}$ Department of Chemistry, Xinxiang Medical University, Jinsui Road 601, Xinxiang, Henan 453003 China \\ ${ }^{b}$ School of Pharmacy, Xinxiang Medical University, Jinsui Road 601, Xinxiang, Henan 453003 China \\ ${ }^{c}$ Department of Chemistry, Nankai University, Tianjin 300071 China
}

(Received: September 10, 2012 - Accepted: April 14, 2013)

\begin{abstract}
Two fluorescent anion sensors bearing phenol, carbazole- $\mathrm{NH}$ and $-\mathrm{NO}_{2}$ group were designed and synthesized. They both exhibited highly binding ability for $\mathrm{H}_{2} \mathrm{PO}_{4}^{-}$among the anions tested. In the presence of $\mathrm{H}_{2} \mathrm{PO}_{4}^{-}$, the fluorescence of the sensors underwent a dramatic enhancement, while the presence of other anions such as $\mathrm{F}^{-}, \mathrm{AcO}^{-}, \mathrm{Cl}^{-}, \mathrm{Br}^{-}$, and $\mathrm{I}^{-}$, had weak or no effect on the fluorescence. The determination limit of two sensors $(\mathbf{1}$ and 2$)$ toward $\mathrm{H}_{2} \mathrm{PO}_{4}^{-}$were $3.0 \times 10^{-7}$ and $5.0 \times 10^{-7} \mathrm{~mol} \cdot \mathrm{L}^{-1}$, respectively. Theoretical investigation indicated it was the highest HOMO to induce the red-shift phenomena of two sensors.
\end{abstract}

Keywords: anion sensor; determination limit; fluorescence; theoretical investigation

\section{INTRODUCTION}

The development of highly selective and sensitive chemosensors for biological important anions is a very active research field in supramolecular chemistry ${ }^{1-10}$. In particular, $\mathrm{H}_{2} \mathrm{PO}_{4}^{-}$-sensitive systems have attracted much interest, as the $\mathrm{H}_{2} \mathrm{PO}_{4}^{-}$ion plays critical roles in a variety of fundamental processes such as energy transduction, signal processing, genetic information storage, and membrane transport ${ }^{11}$. In addition, phosphates can be found in many chemotherapeutic and antiviral drugs. It is for sure that phosphate originating from the over use of agricultural fertilizers can also lead to eutrophication in inland waterways. Thus, the rational design and synthesis of efficient sensors to selectively recognize $\mathrm{H}_{2} \mathrm{PO}_{4}^{-}$analytes is a fundamental goal for supramolecular chemistry.

Accordingly, a variety of sensing systems, involving amide, urea (thiourea), hydrazine, calix[n]arenes, hydroxyl derivatives have been employed for the selective detection of $\mathrm{H}_{2} \mathrm{PO}_{4}^{-12-15}$. While phenol commonly plays an important role in the anion binding site of biological system, very little investigation has been carried out to develop $\mathrm{H}_{2} \mathrm{PO}_{4}^{-}$sensors bearing phenol and carbazole groups.

To our knowledge, the determination limit of the receptor towards anions were rarely reported although it has been widely researched in the cation recognition ${ }^{16,17}$. While it is essential to discuss the determination limit of the receptor towards anions which could provide quantitative basis for the further application in environment, medicine and biology.

Here, we reported the synthesis, anion binding ability and determination limit of fluorescent sensors (1 and $\mathbf{2}$ ) containing phenol and carbazole groups (Scheme 1). The strategy employed in the design of sensors was as following. Firstly, we introduced carbazole and phenol groups, as a fluophore and binding site, into the same sensor molecule which aroused strong fluorescent response. Secondly, to achieve "naked-eye" recognition upon binding of $\mathrm{H}_{2} \mathrm{PO}_{4}^{-}$, we introduced nitro group as a chromophore.<smiles></smiles>

$$
\begin{aligned}
& \text { 1: } \mathrm{R}_{1}=\mathrm{NO}_{2}, \mathrm{R}_{2}=\mathrm{H} \\
& \text { 2: } \mathrm{R}_{1}=\mathrm{H}, \mathrm{R}_{2}=\mathrm{NO}_{2}
\end{aligned}
$$

Scheme 1. Molecular structure of compound $\mathbf{1}$ and $\mathbf{2}$

\section{MATERIAL AND METHODS}

Most of the starting materials were obtained commercially and all reagents and solvents used were of analytical grade. All anions, in the form of tetrabutylammonium salts [such as $\left(\mathrm{n}-\mathrm{C}_{4} \mathrm{H}_{0}\right)_{4} \mathrm{NF},\left(\mathrm{n}-\mathrm{C}_{4} \mathrm{H}_{9}\right)_{4} \mathrm{NCl},\left(\mathrm{n}-\mathrm{C}_{4} \mathrm{H}_{9}\right)_{4} \mathrm{NBr}$, $\left.\left(\mathrm{n}-\mathrm{C}_{4} \mathrm{H}_{9}\right)_{4} \mathrm{NI},\left(\mathrm{n}-\mathrm{C}_{4} \mathrm{H}_{9}\right)_{4} \mathrm{NAcO},\left(\mathrm{n}-\mathrm{C}_{4} \mathrm{H}_{9}\right)_{4} \mathrm{NH}_{2} \mathrm{PO}_{4}\right]$, were purchased from SigmaAldrich Chemical Co., and stored in a desiccator under vacuum, and used without any further purification. Tetra-n-butylammonium salts were dried for $24 \mathrm{~h}$ in vacuum with $\mathrm{P}_{2} \mathrm{O}_{5}$ at $333 \mathrm{~K}$. Dimethyl sulfoxide (DMSO) was distilled in vacuum after dried with $\mathrm{CaH}_{2} \mathrm{C}, \mathrm{H}, \mathrm{N}$ elemental analyses were made on Vanio-EL. ${ }^{1} \mathrm{H}$ NMR spectra were recorded on a Varian UNITY Plus-400 MHz Spectrometer. ESI-MS was performed with a MARINER apparatus. UV-vis titration experiments were made on a Shimadzu UV2550 Spectrophotometer at 298 K. Fluoremetric titrations were performed on a Cary Eclipse Fluorescence Spectrophotometer at $298 \mathrm{~K}$. The binding constant, $K$, was obtained by nonlinear least squares calculation method for data fitting.

3, 6-Dichloro-1, 8-diaminocarbazole was synthesized according to literature ${ }^{18}$

$N, N$ '-Di(l'-methylimino-2'-hydroxyl-3'-nitrobenzene)-3, 6-dichloro-1,8diamino carbazole (1)

3, 6-Dichloro-1, 8-diaminocarbazole (1 mmol, $265 \mathrm{mg})$ and 3-nitrosalicylaldehyde ( $2 \mathrm{mmol}, 334 \mathrm{mg}$ ) were suspended in $35 \mathrm{~mL}$ ethanol. The mixture was heated under refluxing for $4 \mathrm{~h}$. The yellow precipitate was separated by filtration. The solid was washed with diethyl ether and dried under vacuum. ${ }^{1} \mathrm{H}$ NMR (DMSO- $d$ ): $\delta 13.16(\mathrm{~s}, 2 \mathrm{H}, \mathrm{OH}), 12.09(\mathrm{~s}, 1 \mathrm{H}, \mathrm{NH}), 9.21(\mathrm{~s}$, $2 \mathrm{H}), 8.32(\mathrm{~d}, 3 \mathrm{H}), 8.16(\mathrm{dd}, 3 \mathrm{H}), 7.58(\mathrm{~s}, 2 \mathrm{H}), 7.21(\mathrm{t}, 2 \mathrm{H})$. Elemental analysis: 
Calc. for $\mathrm{C}_{26} \mathrm{H}_{15} \mathrm{Cl}_{2} \mathrm{~N}_{5} \mathrm{O}_{6}: \mathrm{C}, 55.34 ; \mathrm{H}, 2.68 ; \mathrm{N}, 12.41 \%$; Found: $\mathrm{C}, 55.42 ; \mathrm{H}$, $2.77 ; \mathrm{N}, 12.09 \%$. ESI-MS $(\mathrm{m} / \mathrm{z}): 562.2$.

$N$, N'-Di(1'-methylimino-2'-hydroxyl-5'-nitrobenzene)-3, 6-dichloro-1,8diamino carbazole (2)

It was synthesized according to the above procedure. ${ }^{1} \mathrm{H}$ NMR (DMSO- $\left.d_{6}\right)$ : $\delta 13.06(\mathrm{~s}, 2 \mathrm{H}, \mathrm{OH}), 12.01(\mathrm{~s}, 1 \mathrm{H}, \mathrm{NH}), 9.20(\mathrm{~s}, 2 \mathrm{H}), 8.81(\mathrm{~s}, 2 \mathrm{H}), 8.31(\mathrm{~d}, 4 \mathrm{H})$, $7.51(\mathrm{~s}, 2 \mathrm{H}), 7.22(\mathrm{~d}, 2 \mathrm{H})$. Elemental analysis: Calc. for $\mathrm{C}_{26} \mathrm{H}_{15} \mathrm{Cl}_{2} \mathrm{~N}_{5} \mathrm{O}_{6}$ : C, 55.34; H, 2.68; N, 12.41\%; Found: C, 55.18; H, 2.96; N, 12.74\%. ESI-MS $(\mathrm{m} / \mathrm{z}): 562.1$.

\section{RESULTS AND DISCUSSION}

\section{$3.1 U V$-vis titration}

The anion sensing ability of compound $\mathbf{1}$ was investigated in DMSO through UV-vis spectroscopy. The changes in UV-vis spectra of compound $\mathbf{1}$ $\left(4.0 \times 10^{-5} \mathrm{~mol} \cdot \mathrm{L}^{-1}\right)$ upon the titration with $\mathrm{H}_{2} \mathrm{PO}_{4}^{-}$were shown in Figure 1. The absorption spectrum of free $\mathbf{1}$ exhibited two broad absorption bands centered at $325 \mathrm{~nm}$ and $425 \mathrm{~nm}$, which could be assigned to the excitation of $\pi$ electrons in the carbazole system and the intramolecular charge-transfer transitions within the whole structure of compound $\mathbf{1}$, respectively ${ }^{19}$. With the stepwise addition of $\mathrm{H}_{2} \mathrm{PO}_{4}^{-}$ion to the solution of compound $\mathbf{1}$, the absorbance intensity at $325 \mathrm{~nm}$ was reduced and the absorbance band at $425 \mathrm{~nm}$ was increased. Simultaneously the absorbance band at $425 \mathrm{~nm}$ shifted to the long wavelength at $500 \mathrm{~nm}$ $(\Delta \lambda=75 \mathrm{~nm})$, and the color of the solution changed from yellow to orangered. After the interation between compounds and phosphate, a small quantity of water was added to the complexation. Interestingly, the addition of protic solvent (such as $\mathrm{H}_{2} \mathrm{O}$ or ethanol) to the solution of complexation $\left(1-\mathrm{H}_{2} \mathrm{PO}_{4}^{-}\right)$ made the orange-red solution change back to the yellow, which suggested the interaction between compound $\mathbf{1}$ and $\mathrm{H}_{2} \mathrm{PO}_{4}^{-}$was hydrogen bond in essence ${ }^{20}$, ${ }^{21}$. Particularly, the presence of $\mathrm{F}^{-}$and $\mathrm{AcO}^{-}$induced similar changes in UV-vis spectrum of 1 compared with $\mathrm{H}_{2} \mathrm{PO}_{4}^{-}$, but the addition of excess equiv of $\mathrm{Cl}^{-}$, $\mathrm{Br}^{-}$and $\mathrm{I}^{-}$ions resulted in slight changes in the $\mathrm{UV}-$ vis spectrum of compound 1 (Figure 2), which indicated compound 1 showed different binding ability with $\mathrm{F}^{-}, \mathrm{H}_{2} \mathrm{PO}_{4}^{-}$, almost no or very weak binding ability with $\mathrm{Cl}^{-}, \mathrm{Br}^{-}$and $\mathrm{I}^{-}$.
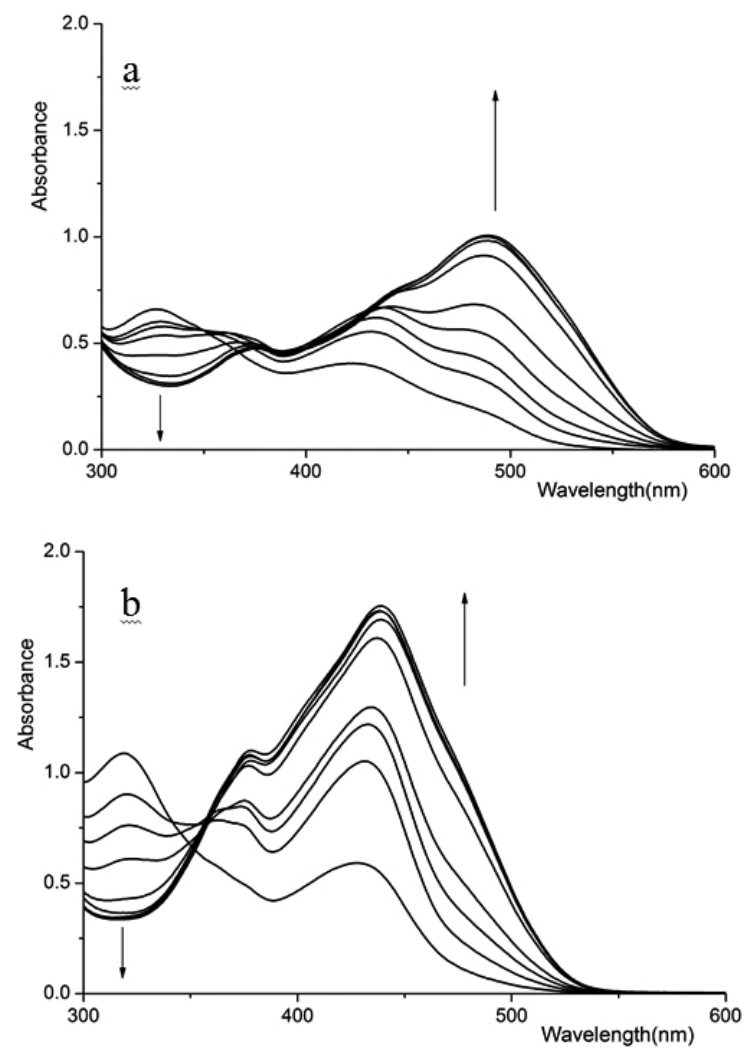

Figure 1. UV-vis spectral changes of compounds $\left(4.0 \times 10^{-5} \mathrm{~mol} \cdot \mathrm{L}^{-1}\right)$ upon the addition of $\mathrm{H}_{2} \mathrm{PO}_{4}^{-}\left(0 \sim 100 \times 10^{-5} \mathrm{~mol} \cdot \mathrm{L}^{-1}\right)$, a) $\mathbf{1}$; b) $\mathbf{2}$. Arrows indicated the increased direction of $\mathrm{H}_{2} \mathrm{PO}_{4}^{-}$concentration.

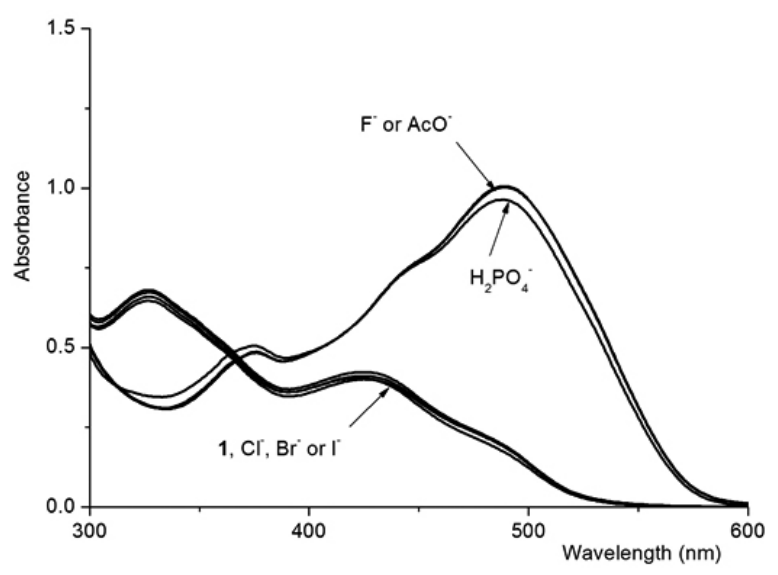

Figure 2. Changes in intensity of the absorption band $(500 \mathrm{~nm})$ in compound $1\left(4.0 \times 10^{-5} \mathrm{~mol} \cdot \mathrm{L}^{-1}\right)$ in presence of anions $\left(8.0 \times 10^{-4} \mathrm{~mol} \cdot \mathrm{L}^{-1}\right)$ tested.

As for free compound 2, the strong absorption at $325 \mathrm{~nm}$ and $425 \mathrm{~nm}$ appeared (Figure 1). With the addition of $\mathrm{H}_{2} \mathrm{PO}_{4}^{-}$ion, the absorption intensity at $325 \mathrm{~nm}$ weakened and a small sharp absorption peak at $375 \mathrm{~nm}$ developed gradually. At the same time the absorption intensity at $425 \mathrm{~nm}$ strengthened and slightly shifted to the long wavelength $(450 \mathrm{~nm}, \Delta \lambda=20 \mathrm{~nm})$. Clearly, redshift phenomenon occurred between compound 2 and $\mathrm{H}_{2} \mathrm{PO}_{4}^{-}$. In addition, one isosbestic point at $360 \mathrm{~nm}$ appeared indicating the stable complex formed ${ }^{22}$. The presence of $\mathrm{AcO}^{-}$and $\mathrm{F}^{-}$induced similar changes in UV-vis spectrum of 2 , but the additions of excess equiv of $\mathrm{Cl}^{-}, \mathrm{Br}^{-}$and $\mathrm{I}^{-}$ions resulted in slight changes in the UV-vis spectrum of $\mathbf{2}$, which indicated the very weak interaction and could be ignored.

\subsection{Fluorescence titration}

The photophysical responses of compound $\mathbf{1}$ toward the addition of anions tested was also investigated in DMSO. Just as Figure 3 showed, upon the addition of $\mathrm{H}_{2} \mathrm{PO}_{4}^{-}$ion (0-10 equiv) to the solution of compound $\mathbf{1}$, the fluorescence centered at $390 \mathrm{~nm}$ when excited at $355 \mathrm{~nm}$ got enhanced. To account for such fluorescence enhancement, the reason was followed: Firstly, before coordination with $\mathrm{H}_{2} \mathrm{PO}_{4}^{-}$ion, the hydrogen atoms of the $-\mathrm{OH}$ group of free 1 could form an intramolecular hydrogen bond with the oxygen atom of $\mathrm{NO}_{2}$, which resulted in a photoinduced electron transfer (PET), and the de-excitation of the resulting tautomer occurred mainly via a nonradiative pathway. These processes consequently led to the weak fluorescence of $\mathbf{1}$. Therefore, an enhancement of the fluorescence emission of $\mathbf{1}$ was observed. Secondly, the configuration of compound $\mathbf{1}$ was flexible and could rotate freely. Upon complexation with $\mathrm{H}_{2} \mathrm{PO}_{4}^{-}$ion, the host molecule 1 was rigidified, which gave birth to a large increase in emission intensity because of inhibiting vibrational and rotational relaxation modes of nonradiative decay. In addition, the addition of $\mathrm{F}^{-}$and $\mathrm{AcO}^{-}$resulted in similar fluorescent changes compared to that of $\mathrm{H}_{2} \mathrm{PO}_{4}^{-}$. Nevertheless, fluorescence emission of sensor $\mathbf{1}$ was insensitive to the addition of excess equiv of $\mathrm{H}_{2} \mathrm{PO}_{4}^{-}, \mathrm{Cl}^{-}, \mathrm{Br}^{-}$and $\mathrm{I}^{-}$ions (Figure 4), which indicated the very weak interaction and could be ignored.

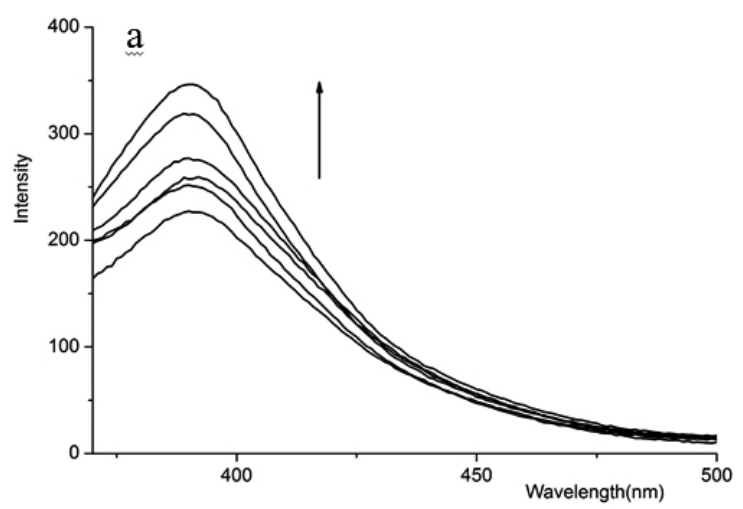




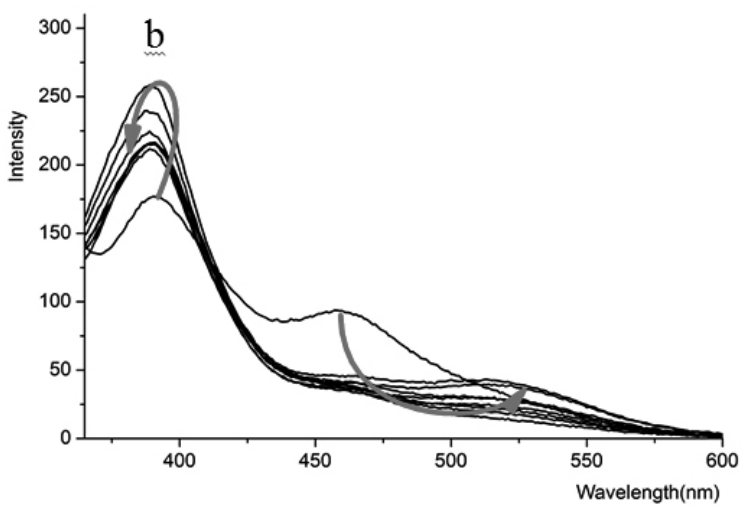

Figure 3. Changes in the emission spectra of compounds $\left(4.0 \times 10^{-5}\right.$ $\left.\mathrm{mol} \cdot \mathrm{L}^{-1}\right)$ in absence and presence of $\mathrm{H}_{2} \mathrm{PO}_{4}^{-}\left(0 \sim 80 \times 10^{-5} \mathrm{~mol} \cdot \mathrm{L}^{-1}\right)$, a) compound $1, \lambda_{\text {ex }}=355 \mathrm{~nm}$; b) compound $2, \lambda_{\mathrm{ex}}=355 \mathrm{~nm}$. Arrows indicated the increased direction of $\mathrm{H}_{2} \mathrm{PO}_{4}^{-}$concentration.

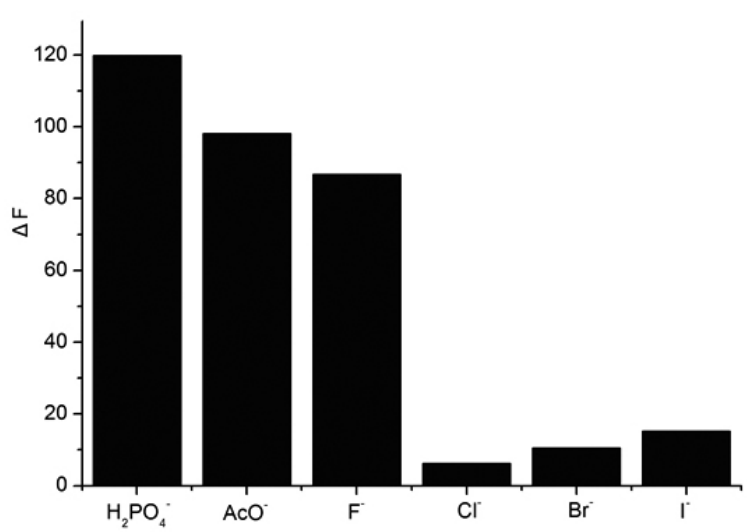

Figure 4. Changes in intensity of the emission band at $392 \mathrm{~nm}$ in compound $1\left(4.0 \times 10^{-5} \mathrm{~mol} \cdot \mathrm{L}^{-1}\right)$ in presence of anions $\left(4.0 \times 10^{-4} \mathrm{~mol} \cdot \mathrm{L}^{-1}\right)$ tested.

For compound 2, the spectral changes induced by anions were clearly different from compound 1 (Figure 3). Two emission peaks at $392 \mathrm{~nm}$ and $460 \mathrm{~nm}$ appeared for free compound 2. As the concention of $\mathrm{H}_{2} \mathrm{PO}_{4}^{-}$was 0.5 equiv, the intensity of emission peak at $392 \mathrm{~nm}$ increased to maximum and decreased to minimum for the emission peak at $460 \mathrm{~nm}$. With the concentration of $\mathrm{H}_{2} \mathrm{PO}_{4}^{-}$increased stepwise (1-10 equiv), the intensity of emission peak at $392 \mathrm{~nm}$ decreased and the intensity of emission peak at $460 \mathrm{~nm}$ increased gradually. To account for such fluorescence phenomenon, the ICT mechanism was exploited. Upon interaction with $\mathrm{H}_{2} \mathrm{PO}_{4}^{-}$, the reduction potential of compound 2 was enhanced, namely the electron transfer from the electron rich phenol moiety bonded with $\mathrm{H}_{2} \mathrm{PO}_{4}^{-}$to the electron deficient $-\mathrm{NO}_{2}$ moiety became more feasible. Upon further addition of $\mathrm{H}_{2} \mathrm{PO}_{4}^{-}$, it appeared that the deprotonated species $\mathrm{LH}^{-}$, being more electron rich compared to the hydrogenbonded complex with $\mathrm{H}_{2} \mathrm{PO}_{4}^{-}$, activated the ICT process more efficiently ${ }^{23}$. Compared with compound $\mathbf{1}$, the different interacted mechanism was induced by the different site which the nitro group existed. There were similar changes in the fluorescence emission of $\mathbf{2}$ induced by addition of $\mathrm{AcO}^{-}$and $\mathrm{F}^{-}$ions with those of $\mathrm{H}_{2} \mathrm{PO}_{4}^{-}$. Nevertheless, fluorescence emission of compound $\mathbf{2}$ was insensitive to addition of excess equiv $\mathrm{Cl}^{-}, \mathrm{Br}^{-}$and $\mathrm{I}^{-}$ions.

3.3 Binding constant

The job-plot analysis indicated the spectral change could be ascribed to the formation of 1:1 host-guest complexation. The obtained binding constants were listed in Table 1 using the method of non-linear least squares calculation according to the UV-vis and fluorescence data ${ }^{24-26}$. The selectivity trend of binding ability of two compounds to anions followed the order of: $\mathrm{H}_{2} \mathrm{PO}_{4}^{-}>\mathrm{AcO}^{-}>\mathrm{F}^{-}>\mathrm{Cl}^{-} \sim \mathrm{Br}^{-} \sim \mathrm{I}^{-}$. It was apparent that the selectivity for specific anions can be rationalized on the basis of the anion's basicity and the interactions between the host and the anionic guests. However, multiple hydrogen-bond interactions were also necessary in high-affinity anion binding sites ${ }^{27}$. As expected from their basicity, $\mathrm{H}_{2} \mathrm{PO}_{4}^{-}, \mathrm{AcO}^{-}$, and $\mathrm{F}^{-}$will bind more strongly than the other anions studied; in addition, the tetrahedron configuration of $\mathrm{H}_{2} \mathrm{PO}_{4}^{-}$ion may well match two compounds in terms of shape and could form multiple hydrogen bonding interaction. Consequently, $\mathrm{H}_{2} \mathrm{PO}_{4}$ ion can be selectively recognized from other anions based on binding constant. For the same anion, the binding ability of compound $\mathbf{1}$ containing $3-\mathrm{NO}_{2}$ was stronger than that of compound 2 containing $5-\mathrm{NO}_{2}$. The reason may be the intramolecular hydrogen bond could improve the acidity of receptor and the anion binding ability could be strengthened. Moreover, the binding constants obtained by UV-vis data were in the same order of magnitude with it obtained by fluorescence data, which indicated the results of binding constants obtained by UV-vis data were proved by fluorescence.

Table 1. Binding constants of compound $\mathbf{1}$ and $\mathbf{2}$ with various anions.

\begin{tabular}{|c|c|c|c|}
\hline Anion $^{\mathrm{a}}$ & & $\mathrm{K}_{\mathrm{s}}(\mathbf{1})$ & $\mathrm{K}_{\mathrm{s}}(\mathbf{2})$ \\
\hline \multirow{2}{*}{$\mathrm{H}_{2} \mathrm{PO}_{4}^{-}$} & Absorption & $(6.15 \pm 0.19) \times 10^{4}$ & $(3.13 \pm 0.68) \times 10^{4}$ \\
\cline { 2 - 4 } & Emission & $(7.58 \pm 0.21) \times 10^{4}$ & $(4.54 \pm 0.21) \times 10^{4}$ \\
\hline \multirow{2}{*}{$\mathrm{AcO}^{-}$} & Absorption & $(2.52 \pm 0.72) \times 10^{4}$ & $(2.19 \pm 0.75) \times 10^{4}$ \\
\cline { 2 - 4 } & Emission & $(3.36 \pm 0.45) \times 10^{4}$ & $(2.47 \pm 0.33) \times 10^{4}$ \\
\hline \multirow{2}{*}{$\mathrm{F}^{-}$} & Absorption & $(1.99 \pm 0.64) \times 10^{4}$ & $(1.22 \pm 0.56) \times 10^{4}$ \\
\cline { 2 - 4 } & Emission & $(2.11 \pm 0.32) \times 10^{4}$ & $(0.97 \pm 0.46) \times 10^{4}$ \\
\hline \multicolumn{2}{|c|}{$\mathrm{Cl}^{-}\left(\mathrm{Br}^{-}\right.$or I- $)$} & $\mathrm{ND}^{\mathrm{b}}$ & $\mathrm{ND}$ \\
\hline
\end{tabular}

a All anions were added in the form of tetra-n-butylammonium (TBA) salts.

${ }^{\mathrm{b}}$ The binding constant could not be determined.

3.4 Interference experiment

The binding ability of compound 1 with $\mathrm{H}_{2} \mathrm{PO}_{4}^{-}$ion was the strongest among the studied anions according to the binding constant. The above results derived from the condition that only one anion existed. We conduct the interference experiment whether the binding ability of $\mathrm{H}_{2} \mathrm{PO}_{4}^{-}$was influenced by other anions (Figure 5). In Fig. 5, the concentration of compound 1 is $4.0 \times 10^{-5} \mathrm{~mol} \cdot \mathrm{L}^{-1}$. According to UV-vis experimental data, when various anions $\left(\mathrm{F}^{-}, \mathrm{AcO}^{-}\right.$and $\left.\mathrm{H}_{2} \mathrm{PO}_{4}^{-}, 8.0 \times 10^{-5} \mathrm{~mol} \cdot \mathrm{L}^{-1}\right)$ were added seperately, the intensity of spetral response of compound 1 were different. As shown in Fig. 5, the spectral response of $\mathbf{1}$ upon the addition of the mixed anions was almost as the same as the addition of $\mathrm{H}_{2} \mathrm{PO}_{4}^{-}$which indicated the binding ability of $\mathrm{H}_{2} \mathrm{PO}_{4}^{-}$with compound 1 was not interfered by the existence of other anions. Similarly, the same result also existed in the interaction of compound 2 with $\mathrm{H}_{2} \mathrm{PO}_{4}^{-}$. This point has experimental and practical importance.

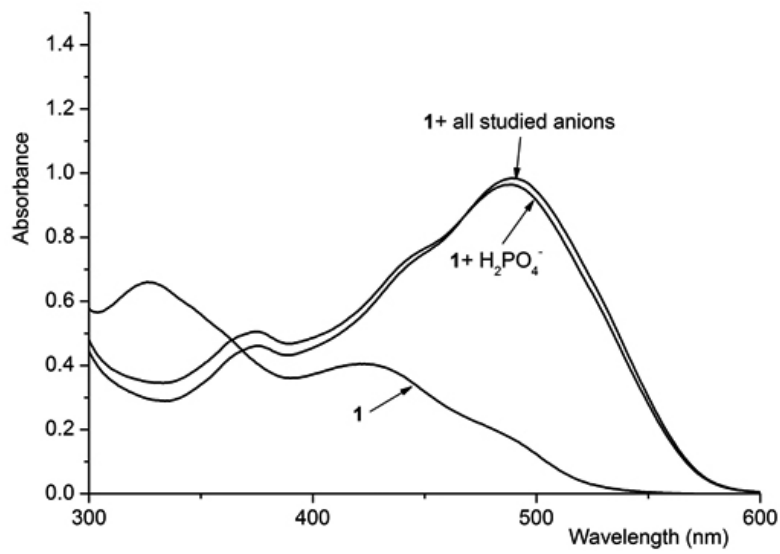

Figure 5. UV-vis spectral changes of compound $1\left(4.0 \times 10^{-5} \mathrm{~mol} \cdot \mathrm{L}^{-1}\right)$ upon the addition of anions $\left(8.0 \times 10^{-5} \mathrm{~mol} \cdot \mathrm{L}^{-1}\right)$.

\subsection{Determination limit}

In cation recognition, determination limit was reported by many literatures 16,17. According to these reported literatures, the intensity in absorption apectra of compounds is lineal at low cationic concentration. While, determination limit of anion was almost reported few. Thus, the determination limit of 
compound 1 to $\mathrm{H}_{2} \mathrm{PO}_{4}^{-}$was studied (Figure 6). The interaction of compound 1 with $\mathrm{H}_{2} \mathrm{PO}_{4}^{-}$could be detected down to at least concentration of $3.0 \times 10^{-7}$ $\mathrm{mol} \cdot \mathrm{L}^{-1}$, at this time the concentration of $\mathrm{H}_{2} \mathrm{PO}_{4}^{-}$ion was $2.3 \times 10^{-7} \mathrm{~mol} \cdot \mathrm{L}^{-1}$. And the corresponding absorption intensity increase to 1.3 times, which showed compound $\mathbf{1}$ could potentially be used as a sensor for monitoring $\mathrm{H}_{2} \mathrm{PO}_{4}^{-}$levels in physiological and environmental systems. Similar experiment indicated the interaction of compound 2 with $\mathrm{H}_{2} \mathrm{PO}_{4}^{-}$could be detected down to at least concentration of $5.0 \times 10^{-7} \mathrm{~mol} \cdot \mathrm{L}^{-1}$, at this time the concentration of $\mathrm{H}_{2} \mathrm{PO}_{4}^{-}$ion was $2.1 \times 10^{-7} \mathrm{~mol} \cdot \mathrm{L}^{-1}$.

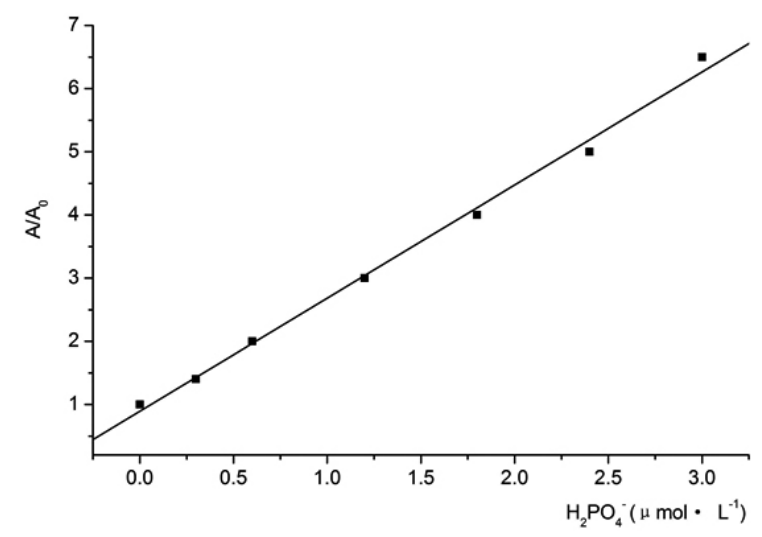

Figure 6. UV-vis intensity of compound $1\left(3.0 \times 10^{-7} \mathrm{~mol} \cdot \mathrm{L}^{-1}\right)$ as a function of concentrations of $\mathrm{F}^{-}\left(0-30 \mu \mathrm{mol} \cdot \mathrm{L}^{-1}\right)$.

\section{$3.6^{1} H$ NMR titration}

To further shed light on the nature of the interaction between two compounds and anions, ${ }^{1} \mathrm{H}$ NMR spectral changes upon the addition of $\mathrm{F}^{-}$ as their tetrabutylammonium salts to the DMSO- $d$ solution of $1,2\left(1 \times 10^{-2}\right.$ $\mathrm{mol} \cdot \mathrm{L}^{-1}$ ) were investigated. Obviously observed from Fig. 7, the peak of compound $\mathbf{1}$ at $13.16 \mathrm{ppm}$, which was assigned to $-\mathrm{OH}$, broadened, exhibited a slightly downfield shift and thoroughly disappeared with the increase of $\mathrm{F}^{-}$ ion. At the same time, the peak at $12.09 \mathrm{ppm}$ which were assigned to $-\mathrm{NH}$, broadened gradually and other chemical shifts of proton peaks almost did not shift indicating the strong hydrogen-bonding interactions occurred between compound $\mathbf{1}$ and $\mathrm{F}^{-}$ion ${ }^{28}$. As for compound $\mathbf{2}$, the peak of $-\mathrm{OH}$ and $-\mathrm{NH}$ occurred at 13.06 and $12.01 \mathrm{ppm}$, respectively. With the stepwise addition of $\mathrm{F}^{-}$, the peak of $-\mathrm{OH}$ broadened, exhibited a slightly downfield shift and thoroughly disappeared which was the same as compound $\mathbf{1}$. However, the peaks of $-\mathrm{NH}$ and other protons shifted to the upfield direction gradually. The reason may be as followed: In compound $\mathbf{2}$, one hydroxyl group formed the structure of ketone and could formed intramolecular hydrogen bonds with - $\mathrm{NH}$ and other hydroxyl group which can be proved by theoretical investigation. With the addition of 0.5 equiv of $\mathrm{F}^{-}$ion, intramolecular hydrogen bond was broken which induced deshielding effect and the proton peak of - $\mathrm{NH}$ group shifted to the upfield direction. With the further addition of $\mathrm{F}^{-}$ion, hydroxyl moiety was deprotonated due to the formation of $\mathrm{FHF}^{-}$. The proton peak of FHF- $^{-}$did not appear which may be related with the small quantity water in DMSO- $d{ }^{29}$. Other protons exhibited a slight upfield shift which indicated the increase of the electron density on them owing to the through-bond effects. The possible binding mode in the solution was showed in Scheme 2.

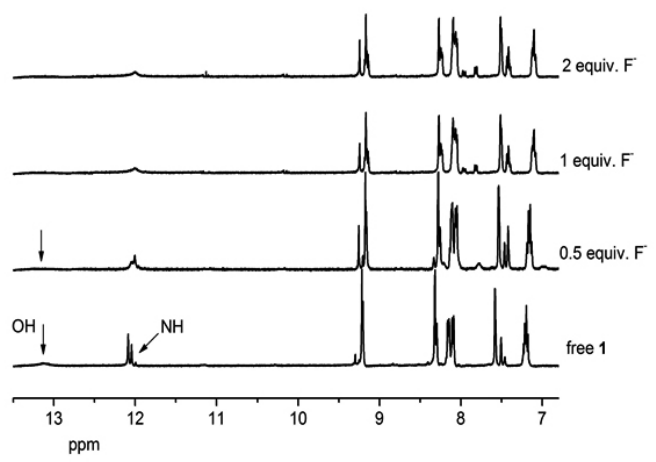

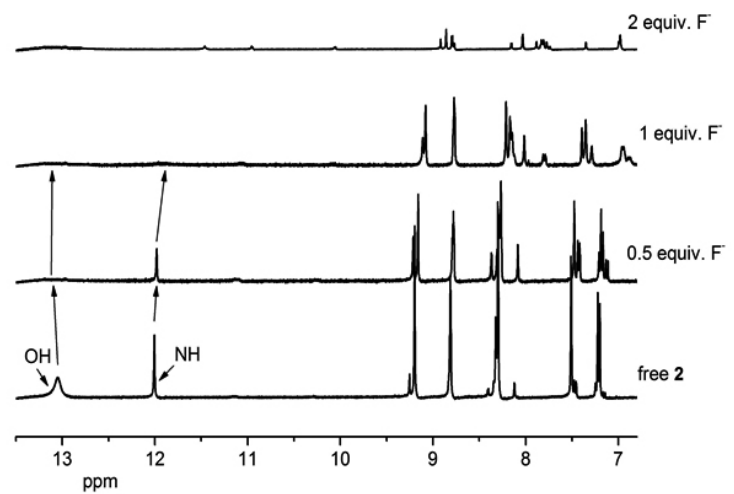

Figure 7. Partial ${ }^{1} \mathrm{H}$ NMR spectrum of compound $\mathbf{1}$ and $\mathbf{2}$ upon the addition of $\mathrm{F}^{-}$.

\subsection{Theoretical investigation}

The geometries of compound 1 and 2 were optimized (Fig. 8) using density functional theory at B3LYP/3-21G level with Gaussian03 program ${ }^{30}$. From Fig. 8, The interacted sites existed in the form of hydroxyl groups of compound $\mathbf{1}$. However, one hydroxyl group in compound $\mathbf{2}$ existed in the form of ketone. The structural difference of two compounds determined the different mechanism in anion recognition. The intramolecular hydrogen bonds also existed between carbozale-NH and hydroxyl group in benzene ring or hydroxyl group and the nitrogen atom.
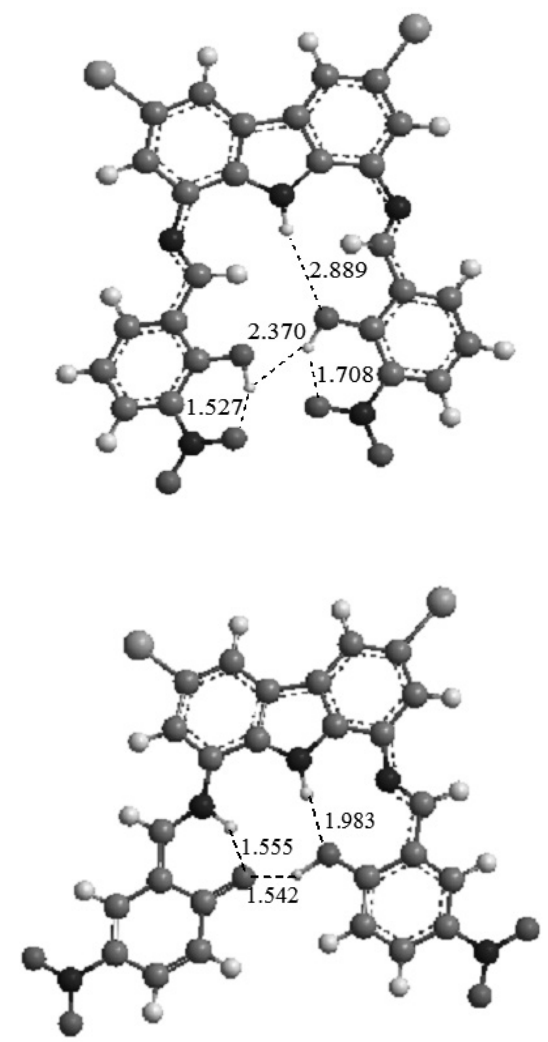

Figure 8. Optimized geometries of compounds $\mathbf{1}$ and $\mathbf{2}$.

In addition, selected frontier orbitals for compound $\mathbf{1}$ and $\mathbf{2}$ were shown in Fig. 9. We introduced molecular frontier orbital in order to explain UVvis absorption spectra in the interacted process of host-guest induced electron transition of frontier orbital. The highest HOMO density in compound $\mathbf{1}$ and $\mathbf{2}$ were mainly localized on the carbazole moiety. While, the highest LUMO density was mainly localized on the one phenyl ring moiety and carbazole 
moiety which demonstrated it was the electron transition of the highest HOMO to arouse the red-shift phenomenon in UV-vis spectra of host-guest.
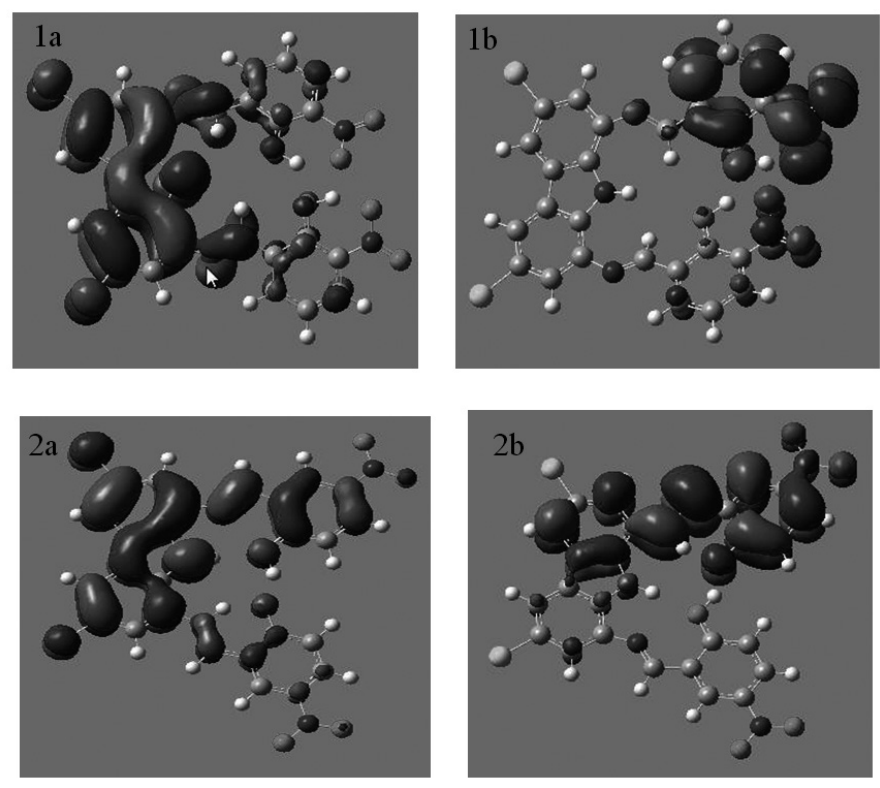

Figure 9. Molecular orbital level of compounds 1 and 2, a) HOMO; b) LUMO.

\section{CONCLUSION}

In conclusion, two fluorescent anion sensors bearing phenol, carbazole$\mathrm{NH}$ and $-\mathrm{NO}_{2}$ group were successfully prepared. The addition of $\mathrm{H}_{2} \mathrm{PO}_{4}^{-}$anion elicited red shift phenomenon in UV-vis spectra and a visible enhancement in the fluorescence emission intensity of sensor $\mathbf{1}$ owing to a quenching PET process from the $-\mathrm{OH}$ to $-\mathrm{NO}_{2}$ group. However, the ICT mechanism of sensor 2 binding anions was exploited. The different interacted mechanism was induced by the different site which the nitro group existed. Theoretical investigation indicated the electron transition of the highest HOMO aroused the redshift phenomenon in UV-vis spectra of host-anion. Particularly, the novel design strategy that the carbazole moiety is incorporated into the fluorescent $p$-conjugated system would help to extend the development of fluorescent anion sensors with the hydroxyl group as anion binding site.

\section{ACKNOWLEDGEMENT}

This work was supported by the Nature Science Fund of Henan Province (2010B150024, 112300410104), Young Teacher Fund of Henan Province (2011GGJS-126) and Doctorial Starting Fund of Xinxiang Medical University.

\section{REFERENCE}

1. C. Caltagirone, P. A. Gale, Chem. Soc. Rev. 38, 520, (2009)

2. X.F. Shang, X.J. Li, C.Z. Li, Y.L. Wang, J.L. Zhang, X.F. Xu, Inorg. Chim. Acta 385, 128, (2012)

3. P. A. Gale, Acc. Chem. Res. 39, 465, (2006)

4. C.R. Bondy, S.J. Loeb, Coord. Chem. Rev. 240, 77, (2003)

5. S.R. Beeren, J.K.M. Sanders, Chem. Sci. 2, 1560, (2011)

6. J.L. Sessler, D.G. Cho, V. Lynch, J. Am. Chem. Soc. 128, 16518, (2006)

7. Z. Xu, S. K. Kim, J. Yoon, Chem. Soc. Rev. 39, 1457, (2010)

8. T. Pinter, F. Ho. Rebecca, J. M. Courtemanche, Chem. Commun. 47, $12688,(2011)$

9. A. Ojida, Y. Mito-oka, K. Sada, I. Hamachi, J. Am. Chem. Soc. 26, 2454, (2004)

10. P.A. Gale, J.R. Hiscock, C.Z. Jie, M.B. Hursthouse, M.E. Light, Chem. Sci. 1, 215, (2010)

11. F. Grases, J.G. March, Anal. Chim. Acta 229, 249, (1990)

12. J. Shao, H. Lin, H.K. Lin, Dyes Pigments 80, 259, (2009)

13. R. Velu, V.T. Ramakrishnan, P. Ramamurthy, J. Photoch. Photobio. A 217, 313, (2011)
14. J.L. Sessler, D.-G. Cho, M. Stepien, V. Lynch, J. Waluk, Z.S. Yoon, D.J. Kim, J. Am. Chem. Soc. 128, 12640, (2006)

15. S. Nishizawa, P. Bühlmann, M. Iwao, Y. Umezawa, Tetrahedron Lett. 36, 6483, (1995)

16. L. Jin, Z. Guo, Z. Sun, A. Li, Q. Jin, M. Wei, Sensors Actuat. B-Chem. 161, $714,(2012)$

17. M. X. Liu, T. B. Wei, Q. Lin, Y. M. Zhang, Spectrochim. Acta A 79, 1837, (2011)

18. M.J. Chmielewski, M. Charon, J. Jurczak, J. Org. Lett. 6, 3501, (2004)

19. T. Gunnlaugsson, P.E. Kruger, P. Jensen, J. Tierney, H.D.P. Ali, G.M. Hussey, J. Org. Chem. 70, 10875, (2005)

20. J. Shao, Y. Qiao, H. Lin, H. K. Lin, Spectrochim. Acta A 71, 1736, (2009)

21. F.-Y. Wu, M.-Z. Sun, Y.-L. Xiang, Y.-M. Wu, D.-Q. Tong, J. Lumin. 130, $304,(2010)$

22. L.H. Tong, B.J. Shen, The physical method in supramolecular chemistry, Science press, Beijing, 2004.

23. K. Ghosh, S. Adhikari, Tetrahedron Lett. 47, 8165, (2006)

24. Y. Liu, B.H. Han, H.Y. Zhang, Curr. Org. Chem. 8, 35, (2004)

25. Y. Liu, C.C. You, H.Y. Zhang, Supramolecular Chemistry, Nankai University Publication, Tian Jin, 2001.

26. J. Bourson, J. Pouget, B. Valeur, J. Phys. Chem. 97, 4552, (1993)

27. I.V. Korendovych, M. Cho, P.L. Butler, R.J. Staples, E.V. RybakAkimova, Org. Lett. 8, 3171, (2006)

28. M. Bonizzoni, L. Fabbrizzi, A. Taglietti, F. Tiengo, Eur. J. Org. Chem. 3567, (2006)

29. D. Esteban-Gómez, L. Fabbrizzi, M. Licchelli, J. Org. Chem. 70, 5717, (2005)

30. M.J. Frisch, G.W. Trucks, H.B. Schlegel, G.E. Scuseria, etc. Gaussian 03, Revision A.1,Gaussian, Inc., Pittsburgh PA 2003. 